\title{
43. LEGS 122 AND 123, NORTHWESTERN AUSTRALIAN MARGIN-A STRATIGRAPHIC AND PALEOGEOGRAPHIC SUMMARY ${ }^{1}$
}

\author{
F. M. Gradstein ${ }^{2}$
}

\section{INTRODUCTION}

The northwestern Australian margin between Exmouth and Scott plateaus is the oldest passive margin of Australia and forms part of the Permian to Cretaceous "Westralian Superbasin" (Yeates et al., 1986). The Exmouth Plateau is a rifted, thinned, and deeply subsided section of continental crust, covered by more than $8 \mathrm{~km}$ of Paleozoic to Mesozoic sediments (Exon and Willcox, 1978). The Exmouth Plateau, about the size of Germany, has water depths of about 2000 to $3000 \mathrm{~m}$ and steep escarpments dropping to the adjacent Argo Abyssal Plain, more than $5500 \mathrm{~m}$ deep, and to the Gascoyne Abyssal Plain, at about 4000 to more than $5000 \mathrm{~m}$ depth. To the east, the plateau has separated from the Northwest Australian Shelf by the downwarped Kangaroo Trough. To the north, west, and south, the plateau is bounded by old oceanic crust underlying the Argo, Gascoyne, and Cuvier abyssal plains, respectively (Fig. 1). The ocean/continent boundary forms (1) a rifted margin east of the Argo Abyssal Plain and west of the Exmouth Plateau, (2) a transform margin south of the Exmouth Plateau toward the Cuvier Abyssal Plain, and (3) a transform margin with short rifted margin segments at the northern Exmouth Plateau toward the Argo Abyssal Plain (Exon et al., 1982).

Leg 122 scientists drilled six sites (up to $1000 \mathrm{~m}$ deep) in two areas of the Exmouth Plateau that penetrated about $3.5 \mathrm{~km}$ of sediment, including $2.4 \mathrm{~km}$ of Mesozoic rocks. During Leg 123, two sites were drilled to basement: one deep site (765) in the Argo Abyssal Plain having a total penetration of $1197 \mathrm{~m}$, including 271 $\mathrm{m}$ of oceanic basement, and one site (766) at the boundary between the Gascoyne Abyssal Plain and twestern Exmouth Plateau (527 $\mathrm{m}$ total depth), that bottomed in a basaltic sill. The Wombat Plateau (northern Exmouth Plateau) Sites 759 through 761, 764, and the Argo Abyssal Plain Site 765 form one major continental margin to deep-ocean basin transect; the second continent to ocean transect consists of the central Exmouth Plateau Sites 762 and 763 , together with Site 766 in the easternmost Gascoyne Abyssal Plain (Figs. 1, 2).

A principal objective for drilling during Legs 122 and 123 was the early evolution of the margin to ocean strata, prior to and during onset of seafloor spreading. The principal accomplishments toward this objective are summarized below, starting with the extensive drilling on the sediment- starved outermost continental margin horst, the Wombat Plateau.

\section{RESULTS OF THE WOMBAT PLATEAU DRILLING (SITES 759 THROUGH 761, 764)}

The Wombat Plateau is a small subplateau having a water depth of about $2000 \mathrm{~m}$ on the northern part of Exmouth Plateau,

\footnotetext{
${ }^{1}$ Gradstein, F. M., Ludden, J. N., et al., 1992. Proc. ODP, Sci. Results, 123: College Station, TX (Ocean Drilling Program).

2 Atlantic Geoscience Centre, Bedford Institute of Oceanography, Dartmounth, N. S. B2Y 4 A2, Canada.
}

near the 5700-m-deep Argo Abyssal Plain (Fig. 1). Figure 2 shows a north-south profile of the Exmouth Plateau, with the small Wombat Plateau separated from the main plateau by the deep Wombat half-graben. This schematic profile shows a conspicuous post-rift unconformity that is underlain by Permian to TriassicJurassic syn-rift sediments characterized by steeply dipping faults. The unconformity is overlain by Cretaceous to Cenozoic post-breakup sediments, commonly more than $1 \mathrm{~km}$ thick.

According to Leg 122 seismic and drilling results on Wombat Plateau, all strata underlying the erosive post-rift unconformity are of Triassic age (Fig. 3). Sites 759, 760, 761, and 764 were drilled to recover a composite late Triassic (-Jurassic) syn-rift through Cretaceous/Cenozoic post-rift record of sediments. The oldest sediments recovered are of mid-Carnian (230 Ma) age; the oldest sediments so far recovered by scientific ocean drilling. During Jurassic time, the horst was uplifted above sea level and subsequently eroded until Tithonian-Berriasian time, when rapid subsidence induced by the onset of spreading on the adjacent Argo Abyssal Plain resulted in marine transgression and the deposition of a thin veneer of Cretaceous and Cenozoic pelagic sediments.

The first evidence for continental stretching dates to Permian time, when extensional tectonics, combined with a marked attenuation of continental crust, were initiated along this north Gondwanan margin (Mutter et al., 1989). Subsidence started during Triassic time, when thick sequences of terrigenous to marginalmarine siliclastic sediments were deposited. During Carnian time (about $230 \mathrm{Ma}$ ago), neritic carbonate rocks were first deposited on Wombat Plateau in a southern embayment of a shallow Tethys sea. Marginal marine clastics were succeeded by alternating shallow-water carbonates and deltaic siliciclastics (von Rad et al., in press). During Leg 122, a 900-m-thick sequence of Triassic sediments was recovered, of which $30 \%$ is shallow-water Tethyan carbonate and the remainder is low-energy paralic to fluvio-deltaic sediments shed from the Gondwanan (Australian) continent to the southeast. During the Norian, a shallowing-upward sequence, more than $300 \mathrm{~m}$ thick, began with shallow-marine limestones interbedded with fluvio-deltaic silty claystone; this graded upward to a deltaic coastal plain facies, with algal mats, coal seams, and root-mottled horizons indicating periodic emergence (von Rad et al., in press).

During latest Triassic (Rhaetian) time, the Wombat Plateau developed a fully marine carbonate sequence. A deeper-water shelf limestone/marlstone section, which in its lithologic alternations resembles the shallowing-upward shelfal-lagoonal Kossen marls in the western Tethys facies of the northern calcareous Alps, is overlain by $\mathrm{a}>200$-m-thick coral and sponge reef complex and a related peri-reefal facies. This facies compares to that of the upper Rhaetian reefal carbonate of the northern calcareous Alps. The discovery of a 200-m-thick Rhaetian reef complex at Site 764 is the first discovery of Triassic reefal material on the Northwest Australian Shelf. Seismic reflection data through Site 764 show that the reef itself corresponds to a seismically "dead" zone, whereas seismic packages around the edges of the reef are consistent with deposition of wedges of prograding reef-derived detritus 


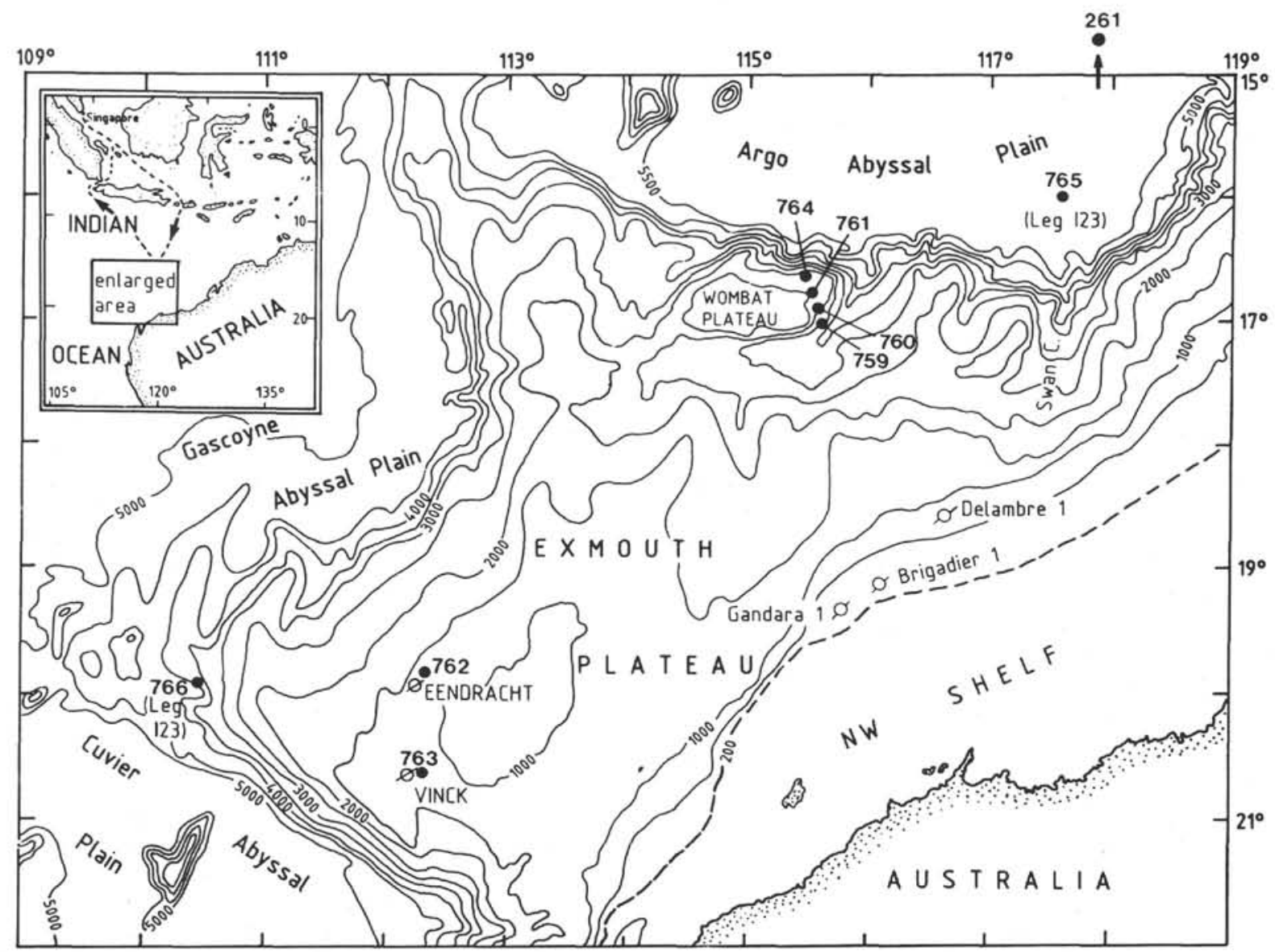

Figure 1. Geography of northwestern Australia and location of sites drilled during Legs 122 and Leg 123, on the Exmouth Plateau and Argo Abyssal Plain. Inset shows route of JOIDES Resolution during Legs 122 and 123. The ocean/continent boundary coincides roughly with the escarpment between Exmouth Plateau, which is continental crust, and the surrounding deep oceanic basins that form the Argo, Gascoyne, and Cuvier abyssal plains.

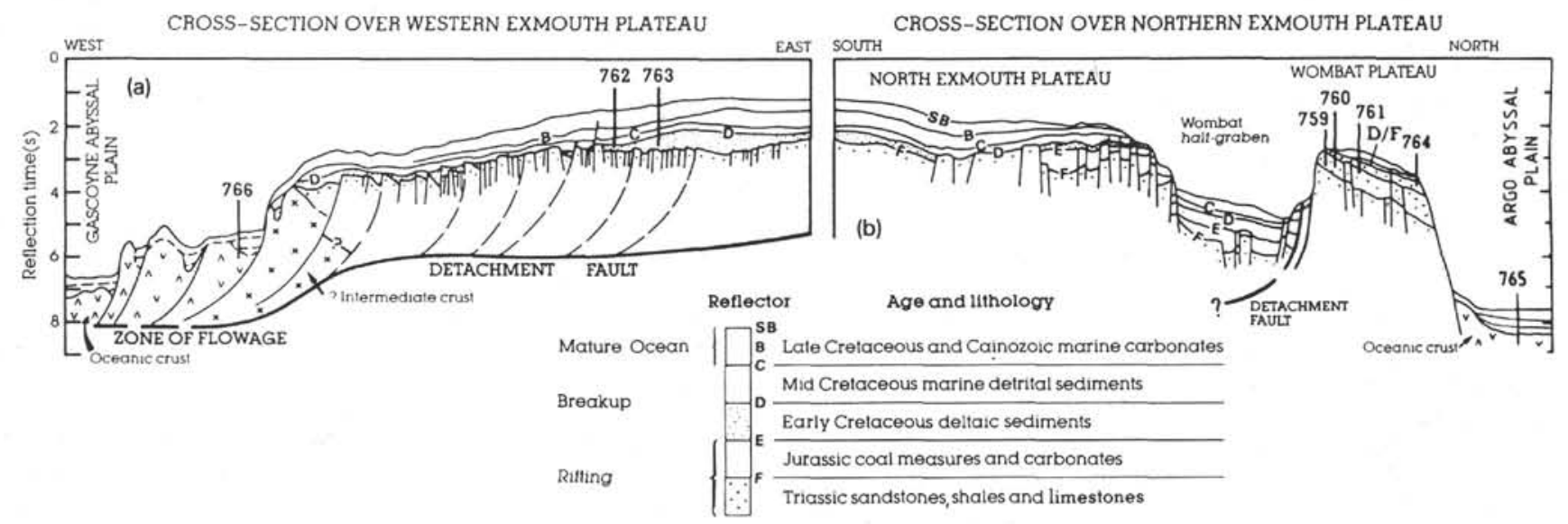

Figure 2. Schematic east-west (A) and north-south (B) geological cross sections across Exmouth Plateau and adjacent abyssal plains, with approximate locations of sites drilled during Legs 122 and 123. For locations see Figure 1. Note the marked post-rift unconformity underlain by block-faulted Triassic-Jurassic sediments overlain by a thin cover of post-breakup sediments (modified after von Rad et al., in press).

(Williamson et al., 1989; Exon et al., 1989). The upper Rhaetian sequence at Site 761 represents a lagoonal facies having mainly foraminiferal packstones and grainstones.

Intertidal algal bindstones, oolite shoals, and local calcisponge patch reefs also occur. This succession is typical for the more landward position when compared to Site 764 , where reefal buildup protected the lagoon from open-marine influences. The sediments document subtropical to tropical water conditions, similar to the present Bahama Bank.

The post-Rhaetian evolution of Wombat Plateau can be inferred only indirectly, because Jurassic sediments are missing as a result of erosion and/or nondeposition. Regional geologic evi- 


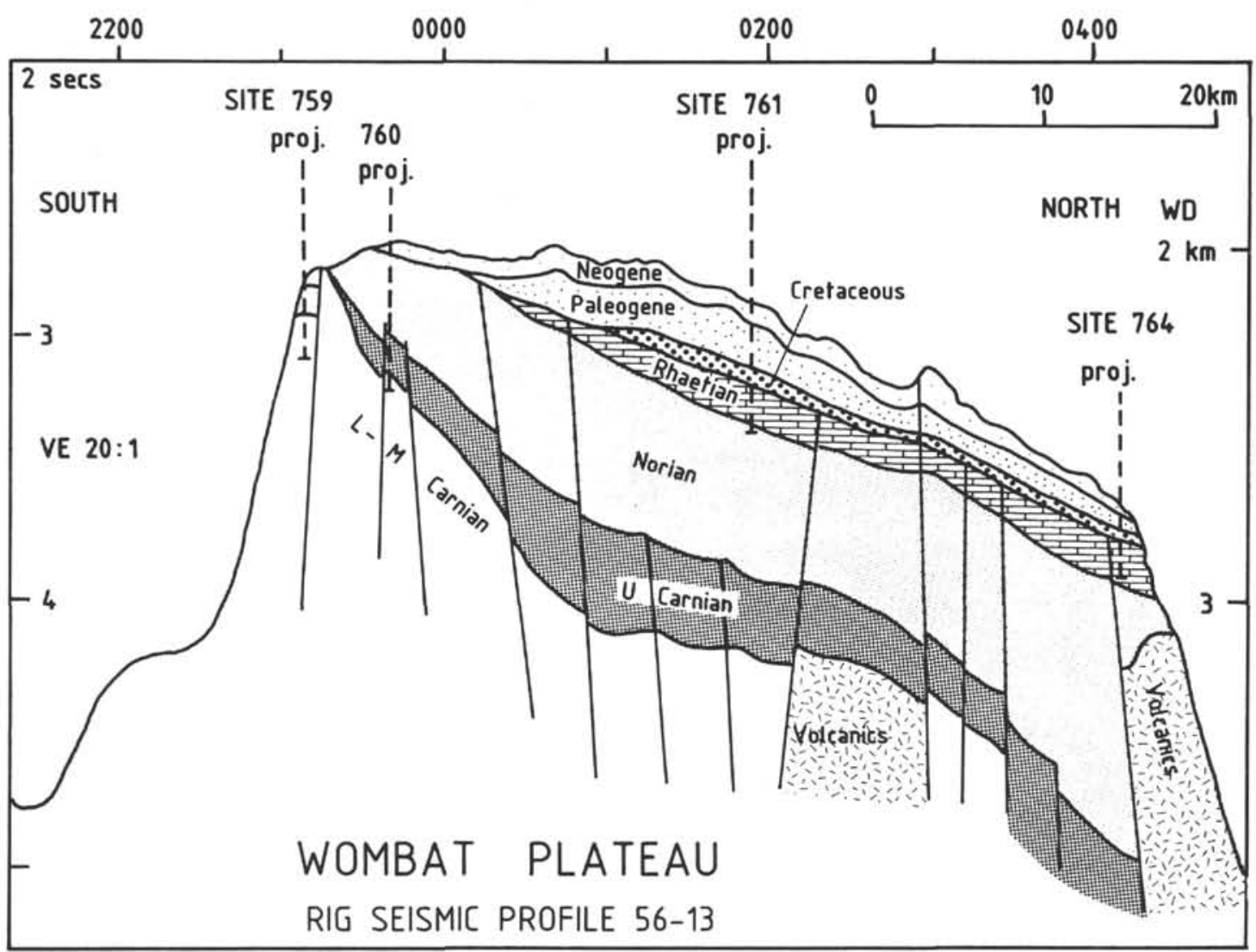

Figure 3. Interpreted multichannel seismic section across Wombat Plateau, with the location of Sites 759 through 761 and 764. The Wombat Plateau is a tectonic horst, which was uplifted during a major Jurassic rift phase, tilted, and then subaerially eroded. Note that gradually younger sediments are preserved northward from Sites 759 to 761 , below the major post-rift unconformity. Note also the thin veneer of Lower Cretaceous through Cenozoic post-breakup sediments (after Haq, von Rad, O'Connell, et al., 1990; Williamson et al., 1989).

dence from seismic profiles indicates that the Wombat Plateau experienced uplift above sea level and northward tilting during a major Jurassic (Callovian/Oxfordian) rift phase (von Rad et al., in press). This "rift-flank tilting" might be explained by isostatic rebound, because the adjacent Wombat half-graben subsided at the same time as the Wombat horst was uplifted. At the northern flank of the uplifted Wombat Plateau, intermediate to rhyolitic volcanic rocks were extruded. These rocks have been dredged and were dated by the K/Ar method as being 190 to 213 m.y. old (von Rad and Exon, 1983). Hence, these rocks document syn-rift volcanism of late Rhaetian to Earliest Jurassic age. An alternative hypothesis, put forward by Sarti et al. (in press) is that Wombat Plateau did not experience any uplift and subaerial erosion, but slow subsidence and extreme condensation (to nondeposition) on a sediment-starved drowned carbonate platform. A third hypothesis to explain local uplift and unconformities is related to the strong volcanic influence along the margin. Part of the syn-rift and seafloor spreading history may be related to a magma plume, which would explain why some of the plateaus and rises are volcanic (Mutter et al., 1989; J. Ludden, pers. comm., 1991). Support for this plume-related influence on the sedimentary record may come from the fact that eastern Indian offshore basins also show a Wombat-type unconformity, with Triassic marine strata unconformably under lower Cretaceous rocks (M. Mohan, pers. comm., 1991).

At about $150 \mathrm{Ma}$, during late Kimmeridgian or Tithonian time, 10 to 15 m.y. later than was predicted both by paleomagnetic
(Larson, 1975) and original biostratigraphic data from DSDP Site 261 (Veevers, Heirtzler, et al., 1974), the oldest oceanic crust was formed at Sites 261 and 765 in the adjacent Argo Abyssal Plain (see below). With the initiation of seafloor spreading and rapid subsidence of the deep ocean basin, Wombat Plateau started to subside below sea level. A condensed sequence of early Neocomian ([?]Berriasian) sand, belemnite sand, and pelagic calcisphere/nannofossil chalk with intercalated bentonitic clay (altered ash) layers (von Rad and Thurow, in press) documents rapid subsidence to bathyal depths during the "juvenile ocean stage." The Turonian marks the onset of the "mature ocean stage" and purely pelagic carbonate sedimentation. During Late Cretaceous and Cenozoic time, the Wombat Plateau continued to subside slowly from a water depth of about 1000 to $2000 \mathrm{~m}$ with decreasing subsidence and sedimentation rates.

\section{RESULTS OF THE ARGO ABYSSAL PLAIN DRILLING (SITE 765)}

The Argo Abyssal Plain, about $5.7 \mathrm{~km}$ deep, is located north of the Exmouth Plateau (Figs. 1, 2). On the north, it is bounded by the Java-Timor Trench of the Banda-Sunda Arc. It is underlain by the oldest oceanic crust known in the Indian Ocean, which since the Cenozoic has been consumed by the convergence of Australia and the Sunda-Banda Arc. Together with the Exmouth Plateau, the Argo Abyssal Plain represents a passive margin and adjacent ocean crust that was starved of sediment owing to the 
low relief of the northwestern Australian craton. The result was a thin (about $1000 \mathrm{~m}$ ) sediment cover at Site 765, which is situated in front of Swan Canyon, at the southernmost limit of the Argo Abyssal Plain.

In the Argo Abyssal Plain, magnetic and seismic surveys (Larson, 1975; Heirtzler et al., 1978; Veevers et al.,1985; Fullerton et al.,1989) clearly show volcanic basement. These studies delineated magnetic anomalies that generally trend $N 70\left({ }^{\circ} \mathrm{E}\right.$. The Oxfordian-Kimmeridgian age of basal sediments at Site 261, and the pattern of these magnetic anomalies led Sager et al. (this volume) to interpret this set of anomalies as M25-M16 in age. This is correlative to the older portion of the standard magnetic anomaly sequence in the Pacific and Atlantic oceans. More recent studies of the Site 261 biostratigraphy and lithostratigraphy, which includes sediment interbedded with the volcanics (Dumoulin and Bown, this volume; Kaminski et al., this volume) indicate that an early Tithonian age for Site 261 basement is more likely.
Paleomagnetically, Site 765 basement is older than that of Site 261 and is of M26 or late Oxfordian age. Site 765 is less than 75 $\mathrm{km}$ seaward from a prominent positive magnetic anomaly that lies along the ocean/continent boundary (COB of Veevers et al., 1985).

The multichannel seismic expression of the strata over the site is shown in a portion of the Australian Bureau of Mineral $\mathrm{Re}$ sources multifold site survey Line 56-23 (Fig. 4). Site 765 spans $1 \mathrm{~s}$ (two-way traveltime) penetration of relatively soft sediments $935 \mathrm{~m}$ thick. Flat-lying sedimentary reflectors contrast with the characteristic hyperbolic reflectance of basement. The site itself is situated over a smooth basement surface, in contrast to the rougher, block-faulted terrain on either side.

At Site 765, Upper Jurassic (Oxfordian; M26 = $164 \mathrm{Ma}$ ) oceanic crust was expected, but the oldest dated sediments are (late) Tithonian, or about 10 to $15 \mathrm{~m} . \mathrm{y}$. younger than predicted from geophysics (Ludden, Gradstein et al., 1990), and younger than those at seaward Site 261. A Tithonian age for oceanic

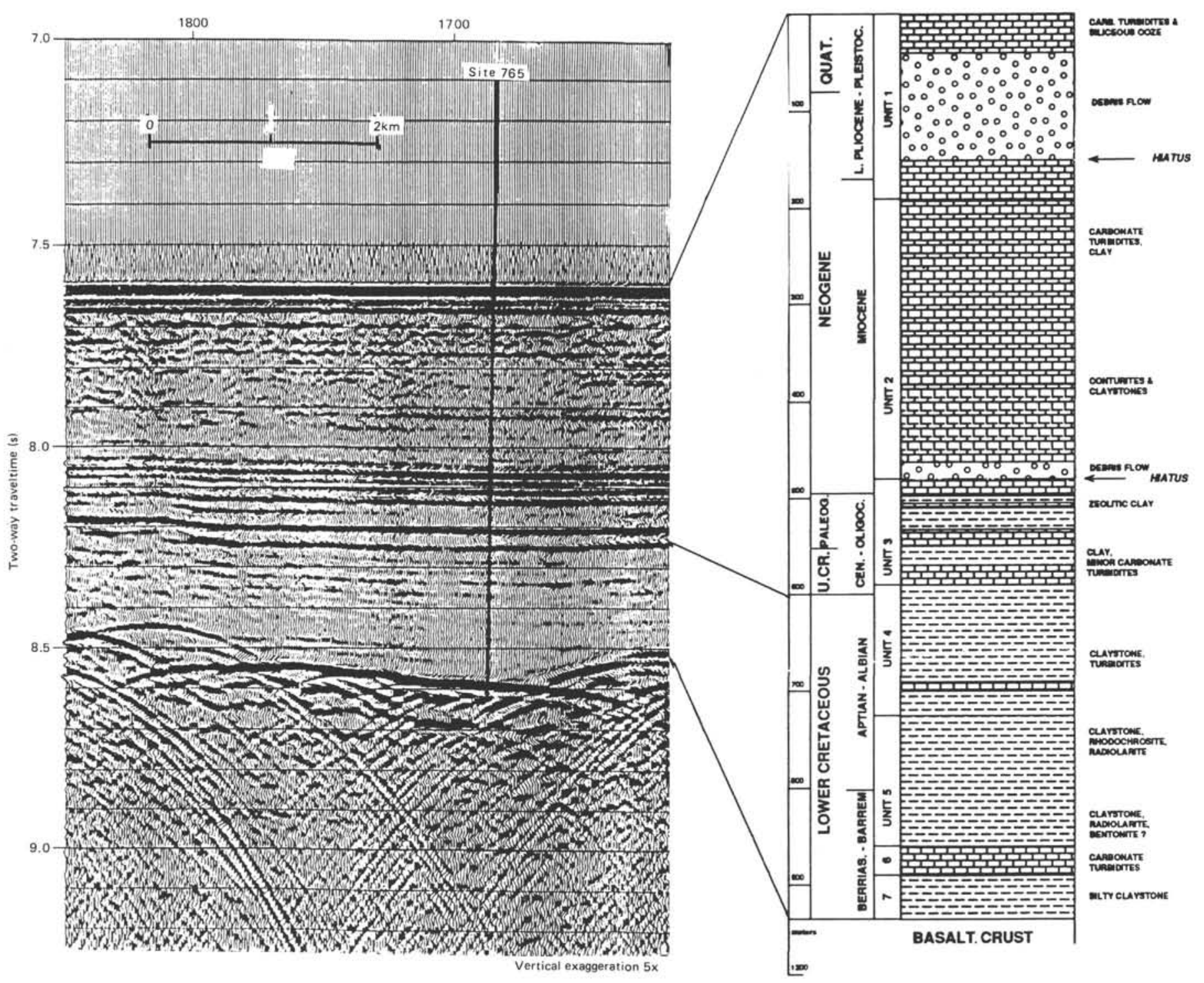

Figure 4. Segment of Rig Seismic Line 65/23C showing location of Site 765, Argo Abyssal Plain, tied to the observed stratigraphy and principal lithologies of oceanic Site 765. Following marine magnetic anomaly information and radiometrics, the ocean crust is likely one or two stages older than the oldest biostratigraphically dated sediments in the site. For explanation see text. 
basement at Site 765 would necessitate revision of most recent published reconstructions of late Mesozoic tectonic history of the northwestern Australian and adjacent parts of the Indian Ocean.

Two K/Ar radiometric dates for oceanic basement at Site 765 , using samples in thick celadonite veins, indicate an age of 155.3 $\pm 3.4 \mathrm{Ma}$ (Ludden, this volume). Attempts to date the basaltic glass resulted in widely varying dates of 111 and $165 \mathrm{Ma}$ (Ludden, this volume), probably the result of the low $\mathrm{K}$ content of these basalts. The new $155 \mathrm{Ma}$ age for celadonite may be more reliable, and certainly is within the margin of error using the uncertainties in both radiometric and marine magnetic anomaly analysis. The celadonite age should represent the age of the low-temperature alteration event that affected the crust, and thus gives a minimum age for basement formation. It should be within $5 \mathrm{~m}$.y. of crustal formation age (Ludden, this volume). This basement age suggests a hiatus of several millions of years at the base of the sedimentary section. This "hiatus" might also be the basal few meters of undated strata.

Site 765 penetrated $271 \mathrm{~m}$ of oceanic basement having relatively fresh glass-bearing basalt, which is similar to mid-ocean ridge basalt (MORB). However, the magmas are more fractionated than most mid-Indian Ocean Ridge (MIOR) basalts, as reflected in high $\mathrm{Fe}$ and $\mathrm{Ti}$ and low $\mathrm{Al}_{2} \mathrm{O}_{3}$ abundances. Higher $\mathrm{CaO}$ and lower $\mathrm{Na}_{2} \mathrm{O}, \mathrm{Zr}$, and $\mathrm{Nb}$ contents than MIOR magmas may reflect a higher percentage of mantle melting for these magmas erupted during the earlier phases of seafloor spreading in the Indian Ocean.

In total, $935 \mathrm{~m}$ of sediment that ranged in age from Earliest Cretaceous to Holocene was cored at Site 765 (Fig. 4). The lower part of the sediment column (upper Berriasian to Valanginian) consists of dark-brown, laminated calcareous claystones with mollusk debris (principally Inoceramus shell fragments) and with rare radiolarians. Calcareous material in this interval has corroded, and nannofossils consist exclusively of the robust species Watznaueria deflandrei. The benthic foraminiferal assemblage in this sediment interval is composed wholly of agglutinated forms. This evidence indicates deposition of these sediments at or just below the calcite compensation depth (CCD). The sediment/basement contact is marked by a thin layer of red noncalcareous clay that contains hyaloclastic basalt fragments formed atop the uppermost basalt flow.

The Lower Cretaceous section is dominated by red, brown, and green claystones, although significant calcareous and lesser siliciclastic turbidite deposition occurred during Valanginian, Hauterivian, and late Aptian time; dark-gray organic-rich claystones also occur in the Aptian sequence, probably the local expression of the Tethyan "Selli Event" (Global Oceanic Anoxic Event 1). Greenish-gray to gray, waxy claystones containing degraded glass shards, feldspar crystals, and clays exclusively of the smectite group have been interpreted as redeposited altered ash layers (Thurow and von Rad, in press). The same authors also found altered ash layers of essentially the same age (late Berriasian to early Valanginian) as those found at Site 761 on the adjacent Wombat Plateau.

The Upper Cretaceous to Paleogene interval in Site 765 consists of clays and interbedded siliciclastic or calcareous turbidites and represents a transition between late Aptian-Albian hemipelagic clay sedimentation and Neogene turbidite sedimentation.

Calcareous and siliciclastic turbidites range in thickness from about $10 \mathrm{~cm}$ to more than $5 \mathrm{~m}$. Significant turbidite deposition first occurred during the Valanginian, but has completely dominated sedimentation since the Eocene. The sediments comprising these turbidites probably came from one or more of the prominent submarine canyons that incise the northern margin of the North- west Australian Shelf. One likely candidate is the large Swan Canyon, south of Site 765 (cf. von Stackelberg et al., 1980).

\section{RESULTS OF CENTRAL EXMOUTH PLATEAU DRILLING (SITES 762 AND 763)}

From the central Exmouth Plateau sites (Sites 762,763; Figs. 1,2 ), an almost complete, composite section was recovered (more than $1400 \mathrm{~m}$ thick) of late Tithonian/Berriasian to Valanginian syn-rift deltaic claystone and Hauterivian to Quaternary hemipelagic to eupelagic marls, chalks, and oozes (Fig. 5). Sequence stratigraphic analysis of the complete Berriasian to Quaternary succession at Sites 762 and 763 , which was derived from a synthesis of seismic stratigraphy (Barber, 1982) and commercial wells, can now be verified by multiple lithostratigraphy, biostratigraphy, and magnetostratigraphy, as well as by wireline logs. Our results indicate that a thick terrigenous clastic wedge prograded between Tithonian and Valanginian time from an uplifted hinterland to the south of Site 763 , northward onto subsiding continental crust. More than $1700 \mathrm{~m}$ of marine deltaic sediments was deposited in less than 6 m.y. over a $300 \mathrm{~km}$ wide clastic wedge, showing at least five depositional episodes. Well-defined wireline logs correlate the rapidly deposited, 700-m-thick progradational prodelta claystone recovered in these holes with seismically detected clinoforms and cored intervals of shingled basin floor turbidites, documenting the lowstand prograding complex during lowstands of sea level (Boyd et al., in press; Erskine and Vail, 1988). Sequence boundaries recognized in the upper Berriasian and lower Valanginian of the central Exmouth Plateau Sites 762 and 763 correlate well with the global cycle chart (Haq et al., 1988). However, an excess of sediment supplied during synrift subsidence may override the eustatic signal (Boyd et al., in press).

The termination of the rift stage and the time of breakup of the western and southern margins of the Exmouth Plateau are constrained by the pre-mid-Hauterivian erosional unconformity and the underlying Valanginian transgressive sandstone. Hence, the early breakup is likely late Valanginian to early Hauterivian in age. It is associated with intense uplift of the area of the later Cape Range Fracture Zone (Boyd et al., in press), and correlates well with the breakup in the oldest part of Gascoyne Abyssal Plain about 130 m.y. ago (M10), documented by the uppermost Valanginian sediments directly overlying "oceanic basement" at Site 766. A transgressive interval of Valanginian age is represented by a 25 -m-thick, condensed section of glauconite and quartz-rich, carbonate-cemented sandstone with rare belemnites.

A Hauterivian to early Aptian claystone at Sites 762 and 763 is rich in organic matter and was deposited in a neritic, shelf environment ("Muderong Shale equivalent"). During Hauterivian/Barremian to Cenomanian time, when the former southern hinterland started drifted northwestward as part of "Greater India," the associated southern clastic supply was cut off, which explains predominantly fine-grained sedimentation. Younger, Albian-Coniacian mudstone, marl, and deep-water claystone and marl featuring cyclic sedimentation mark the transition of hemipelagic deposition during the "juvenile ocean stage" to the "mature ocean stage." High organic productivity and supply to the continental margin Site 763 produced a thin black shale containing up to $25 \%$ organic carbon at the well-known global Cenomanian-Turonian boundary event, whereas (for unknown reasons) the abyssal Sites 765 and 766 hardly received any (J.Thurow, pers. comm., 1990). Post-Cenomanian deposition gradually was dominated by pelagic carbonate, reflecting effective trapping of terrigenous clastics by the Kangaroo Trough. The Paleocene/Eocene unconformity at Site 763 (Fig. 5), a 30 m.y. hiatus, was probably caused by nondeposition on the continuing topographic 


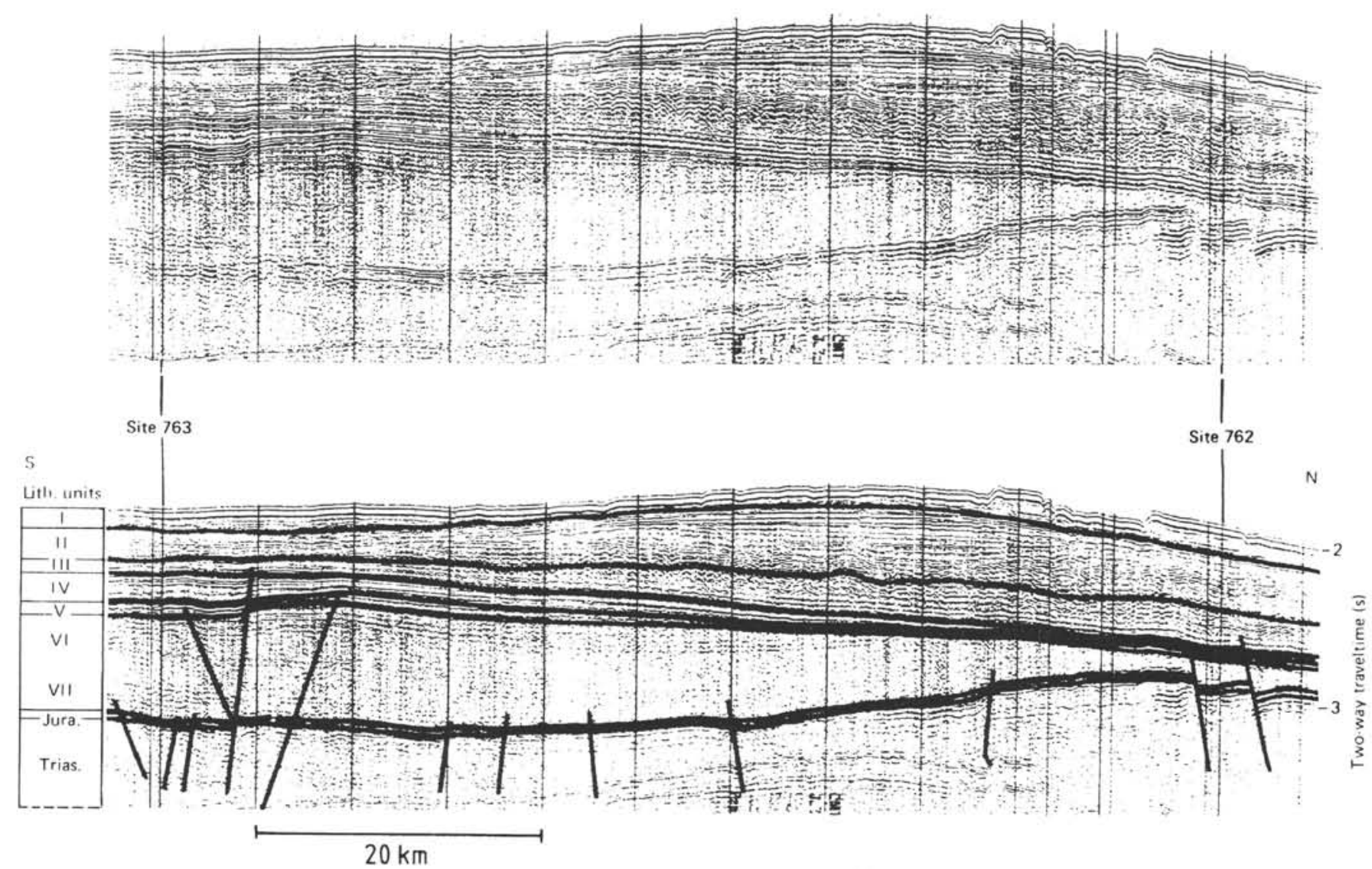

Figure 5. Uninterpreted and interpreted single-channel seismic line through Sites 762 and 763 on the central Exmouth Plateau (Figs. 1, 2). Unit I = late Oligocene to Quaternary, Unit II = middle Eocene to early Oligocene, Unit III = Paleocene to Eocene, Unit IV = middle Aptian to Maestrichtian, Unit $\mathrm{V}=($ ?)Hauterivian to early Aptian, Units VI and VII = early Berriasian to Valanginian. Note thinning of the Berriasian to Valanginian clastic wedge (Units VI and VII) and thickening of the lower Cenozoic sequence from north to south.

high along the southern margin. Pelagic carbonate deposition was continuous in the north (Site 762) and started at Site 763 in middle Eocene time.

\section{DRILLING RESULTS IN THE EASTERN GASCOYNE ABYSSAL PLAIN AT THE WESTERN FOOT OF THE EXMOUTH PLATEAU ESCARPMENT (SITE 766)}

Site 766 is located at the base of the steep western margin of the Exmouth Plateau (Figs. 1, 2). Australian Bureau of Mineral Resources Rig Seismic Line 55 crosses the site (Fig. 6). The seafloor represents an erosional surface with a veneer of Pleistocene-Pliocene on Eocene nannofossil oozes. The oldest sediment penetrated is uppermost Valanginian sandstone and siltstone, which has been interbedded with inclined basaltic sills of $\mathrm{Fe}$-rich tholeiitic composition. We do not know whether these intrusions grade into "true oceanic basement," or whether Site 766 is underlain by an extensive sediment/volcanic complex. According to the marine magnetic anomalies interpretation of the Gascoyne Abyssal Plain, Site 766 is a few kilometers landward of chron M10 (Fullerton et al., 1989; Sager et al., this volume). Seafloor spreading is thought to have started at M10 time, at the Valanginian/Hauterivian boundary, with a spreading jump seaward between M5 and M4 time (late Hauterivian). Hence, the breakup between western Australia and "Greater India," which led to the formation of the Gascoyne Abyssal Plain, occurred about 134 m.y. ago
(Fullerton et al., 1989). This is in good agreement with Site 766's true oceanic basement of late Valanginian age.

At least $300 \mathrm{~m}$ (approximately $65 \%$ ) of the sediments penetrated accumulated during the Lower Cretaceous, compared to roughly $150 \mathrm{~m}$ thereafter. Site 766 appears to have remained above the CCD throughout its history. A total of $466.7 \mathrm{~m}$ of Pleistocene to upper Valanginian or Hauterivian sediments was cored (Fig. 6).

The dominant lithologies in Subunit IIIB (uppermost Valanginian to Hauterivian) are dark greenish-gray silty sandstones and sandy siltstones, with well-rounded glauconite grains and echinoderm fragments and altered volcaniclastic grains, as well as quartz sand and silt. Clay-sized material is rare. Normal grading is the most common sedimentary structure within the coarser-grained lithologies.

This interval constitutes a wedge of redeposited shallow marine sediment that thickens eastward toward the Exmouth Plateau, and southward toward the Cuvier Abyssal Plain. The scarcity of sedimentary structures typically associated with turbidites and the conspicuous absence of clay-sized material required for sustaining turbidity current transport suggest that grain flow transport may be the dominant process of redeposition. Upwardcoarsening of the sequence indicates progradation of a submarine fan composed of sediment derived from the adjacent Exmouth Plateau.

Thin, waxy clay laminae in the lower part of Subunit IIIB have been interpreted as bentonites. The bentonites at Site 766, which 

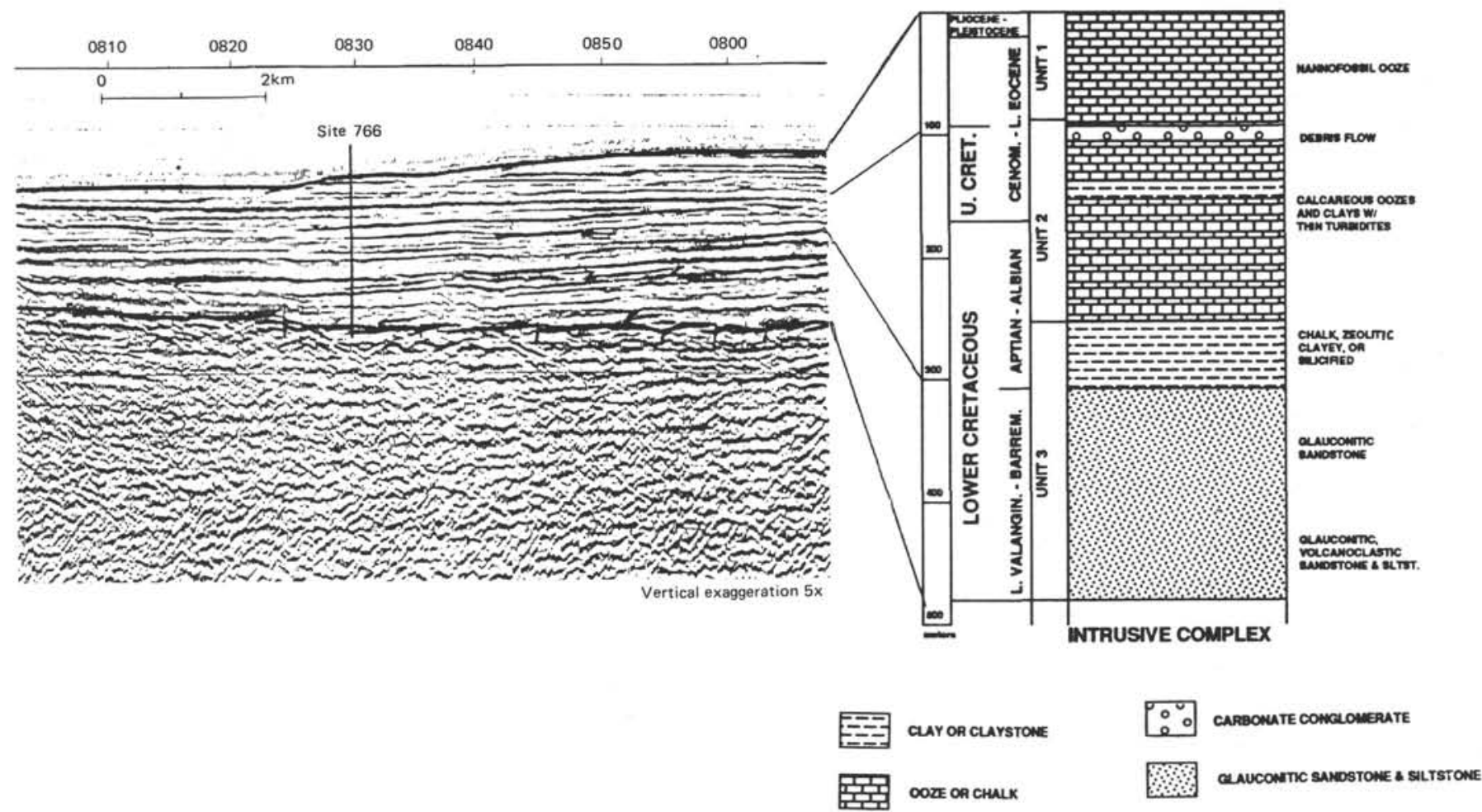

Figure 6. Segment of Rig Seismic Line 55/2 showing location of Site 766 at the foot of the western escarpment of the Exmouth Plateau leading westward to the Gascoyne Abyssal Plain, tied to observed stratigraphy and principal lithologies of Site 766 .

site only originated in late Valanginian time, are a few m.y. younger than those at Sites 765 and 761, where the bentonites are late Berriasian-Valanginian in age. A common source, perhaps one of the Lower Cretaceous volcanic features of the Wallaby Plateau or at the Roe Rise (northwestern Exmouth Plateau), is likely for the altered ash layers in these three areas (von Rad and Thurow, in press).

Subunit IIIA consists predominantly of greenish-gray claystone containing abundant silt- to sand-sized glauconite and up to $50 \%$ radiolarians. Common, coarser-grained intercalations consist predominantly of glauconite, quartz, and calcite bioclasts. This facies apparently signals redirection or abandonment of the fan system, possibly related to the late Hauterivian to Barremian highstand of sea level proposed by Haq et al. (1988).

The Barremian/Aptian boundary represents a marked change in sedimentation from clayey and sandy submarine fan deposits to a condensed Aptian to lower Paleogene sequence of pelagic and hemipelagic nannofossil oozes. The transition from rapidly deposited clastic sediments to slowly deposited pelagic and hemipelagic oozes in Barremian-Aptian time appears to mark the transition from juvenile to mature oceanic conditions. Similar reduction of sedimentation rates at Sites 765 and 261 (see below) during the Late Cretaceous implies a global tectonic and/or sealevel event.

\section{PALEOGEOGRAPHIC RECONSTRUCTION}

Paleomagnetic reconstructions discussed in Gradstein et al. (in press) and Ogg et al. (this volume) indicate that Australia, Antarctica, and "Greater India," which included northern Nepal, formed part of the southern landmass of Gondwana during Jurassic time (Sengör, 1985). Paleomagnetic results for several Mesozoic formations in Thakkhola, Nepal, have yielded a polar-wander path similar to that from the Indian subcontinent and to Jurassic poles from other Gondwanan fragments transferred to the Indian subcontinent.

Figure 7 shows a paleogeographic reconstruction for earliest Berriasian time, $10 \mathrm{~m} . \mathrm{y}$. or more prior to the breakup between Australia and India. This is the time when seafloor spreading had just begun between a hypothetical Argo landmass in the north and a northern Exmouth Plateau. The close proximity, highlighted in the detailed reconstruction of northwestern Australia, India, and Thakkhola, Nepal, during Earliest Cretaceous time, might explain similarities in stratigraphic evolution of these regions, as summarized in the next section.

\section{TRENDS IN MESOZOIC SEDIMENTATION, NORTHWESTERN AUSTRALIA AND THAKKHOLA, NEPAL}

Figure 8 shows a comparison of the Thakkhola, Nepal, sedimentary sequence with sequences drilled off northwestern Australia, on the Exmouth and Wombat plateaus (Sites 759 through 764), on the Argo Abyssal Plain (Site 765) and on the western foot of the Exmouth Plateau, facing the Gascoyne Abyssal Plain (Site 766). It is not difficult to see that several important similarities stand out. First, in both northwest Australia and Thakkhola, Bahama-type carbonate platform deposits occur in late Triassic through Early Jurassic time, when both areas occupied relatively low, subtropical latitudes and faced the neo-Tethys Ocean to the north. Second, the onset of claystone sedimentation in central Exmouth Sites 762 and 763 appears to coincide well with the shale sedimentation in Late Jurassic time in Nepal, when both areas were south of the carbonate belt. Gradual basinal deepening prior to breakup and a generally wet climatic regime may be responsible for the widespread shale deposition. Tithonian-Berriasian breakup and oceanization on the Argo Abyssal Plain coincides 


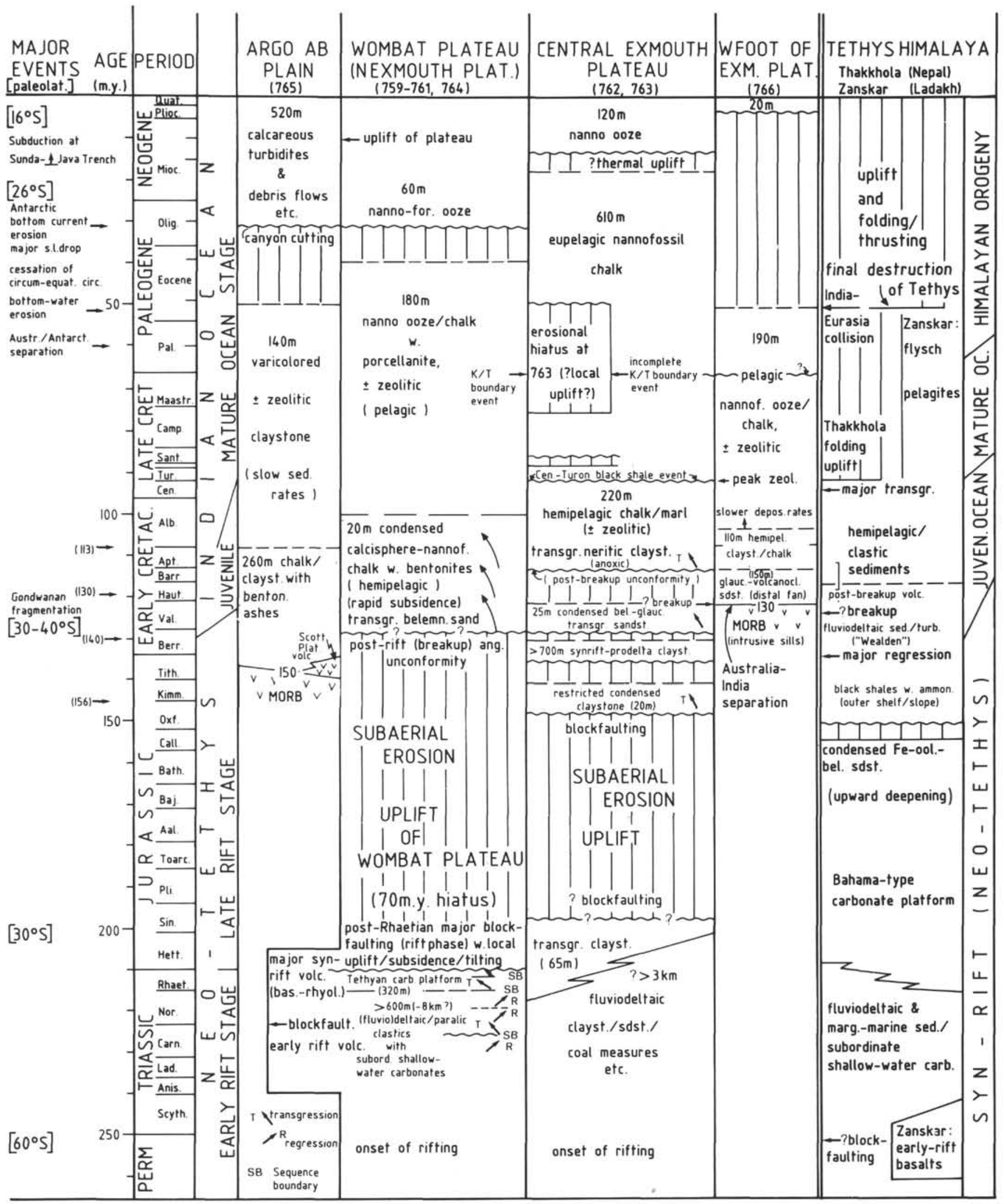

Figure 7. Stratigraphic summary of structural and paleoenvironmental evolution of Leg 122 and 123 sites and Thakkhola, Nepal, during the past 250 m.y. 


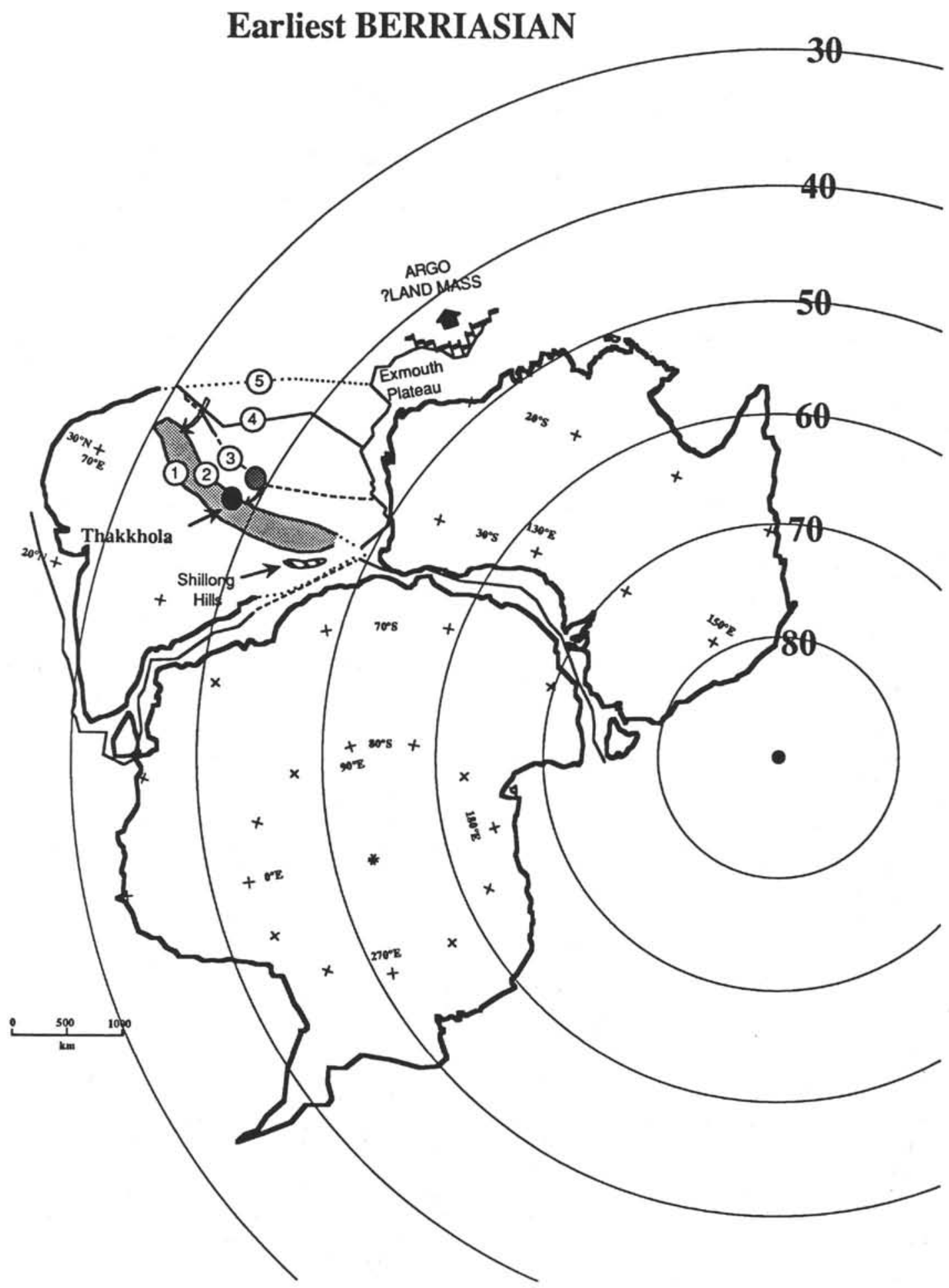

Figure 8. Reconstruction of east Gondwanaland in Earliest Cretaceous (earliest Berriasian) time. Sri Lanka rotated by $8.5^{\circ}$ clockwise about $10^{\circ} \mathrm{N}, 80^{\circ} \mathrm{E}$ before being rotated with India. In India, the Shillong Hills indicate the minimum eastward extent of India. Line 1 = present Main Boundary Fault of the Himalayas; Line 2 = Indus-Tsangpo Suture; Line $3=$ minimum northward extent of India in East Gondwanaland after unwinding the doubled thickness of the crust south of the Indus-Tsangpo Suture; Line 4 = Kun Lun-southern Tsaidam mountain front; line 5 = postulated northern edge of greater India. All lines are rotated fixed relative to India. The projection is Lambert equal-area. 
with fluvio-deltaic sequences of the Chukh Formation in Nepal and glauconite sands on central Exmouth, which probably relates to widespread mobilization of relief. Initiation of seafloor spreading between Australia and Greater India in late Valanginian time, as dated in Site 766, may coincide with post-breakup volcanics in the Kagbeni unit of Thakkhola. The onset of the appearance of detrital volcanic minerals in the Lower Cretaceous sections of Thakkhola, Nepal, awaits precise dating. At present, we know that it is after Valanginian and before Albian time. A global, first-order rise in sea level throughout Aptian-Albian time, combined with sustained, thermally induced deepening on the Exmouth Plateau, led to widespread hemipelagic, chalky sedimentation, reflected in the Dzong Formation in Thakkhola, Nepal. After Albian time, Australia and Nepal diverge in geologic record, with Thakkhola, Nepal, experiencing emergence, folding, and uplift, and northwestern Australia maintaining its late-stage passive margin subsidence and distal sedimentation profile.

Because the sedimentary, paleomagnetic, and general paleogeographic evidence presented sofar supports Thakkola, Nepal, and northwestern Australia as "nearby" on northeastern Gondwana, until at least Early Cretaceous time, it is relevant to analyze burial and subsidence trends for similarities. The analysis may assist with differentiation of local and regional trends in tectonics and sedimentation.

Starting with northwestern Australia, our basic data are the detailed stratigraphic data and physical property results for the ODP sites (von Rad et al., 1989; Haq, von Rad, O'Connell, et al., 1990; Ludden, Gradstein et al., 1990). Data from Site 763 on the central Exmouth Plateau was combined with the lithostratigraphic information from the nearby Vinck-1 commercial well to extend to the upper Triassic Mungeroo Formation.

Our analysis started with the backtracking of each of the oceanic sites to determine the initial ridge-crest depth below sealevel, the subsidence track of the basement/sediment interface and that of the successively younger sedimentary units that once formed the seafloor. We used the Fortran 77 program BTRACK, written by $Z$. Huang (Dalhousie University, Halifax), based on the empirical equations relating age since formation of the oldest, ridge-crest volcanics and water depth for the 0-70 and 70-160 Ma intervals (Sclater et al., 1985). The program corrects for basement loading from sediment buildup and compaction of the sediments. The geological time scale follows Kent and Gradstein (1985).

The Kimmeridgian-Tithonian ridgecrest depth for Site 765 was $2834 \mathrm{~m}$, which is consistent with a normal ridge crest depth and supports the basement age of $155 \mathrm{Ma}$; the Tithonian ridge crest depth for Site 261 was $2439 \mathrm{~m}$. For Site 766 , the initial water depth was $800 \mathrm{~m}$, assuming that the site behaved like an oceanic one, it being on the ocean/continent boundary. This water depth is plausible, given the grain flow-type fan sediments on basement, with reworked shallow marine components (Ludden, Gradstein et al., 1990).

Next, the calculated paleowater depths through time for Sites 261,765 , and 766, together with the estimates, using biota, sedimentology, and interpolations for the Wombat and central Exmouth plateaus, were used as input in the program BURSUB (Stam et al., 1987; Gradstein et al., 1989a). This Fortran 77 program calculates the restored sedimentation, burial, and subsidence rates of sedimentary units in each well site through time. Corrections were applied for increased compaction of the sedimentary units through time with deeper burial and changes in sea-level elevation relative to the Holocene. An additional program, DEPOR, calculates decompaction functions based on several hundred porosity/depth and grain density measurements per well site. It is these decompaction functions that BURSUB use for decompaction. Basement unloading to arrive at tectonic subsidence is based on Airy-type of local compensation; no corrections were attempted for flexural loading (cf. Cloetingh et al., this volume).

Less detailed information is available for the composite stratigraphic site constructed for Thakkhola, Nepal (Gradstein et al., $1989 \mathrm{~b}$; in press), but the small water depth of the sedimentary deposits makes errors in paleobathymetric estimates unlikely. The physical property data were estimated, using default-type global porosity/depth per lithology values stored in the program. No detailed analysis was made of the post-Mesozoic (uplift) history of Thakkhola, because we focus on the first-order Mesozoic syn-sedimentary basin history. A review of recent knowledge of the uplift history of the Himalayan mountain chain is in LeFort (1989).

An initially high (Permian) Triassic subsidence and sedimentation rate, exceeding $10 \mathrm{~cm} / \mathrm{k} . \mathrm{y}$. on the northwestern Australian margin and probably also in Thakkhola, Nepal (but not studied stratigraphically), in Jurassic time is followed by a nondepositional trend (Figs. 9 through 11). Such is not the case in Nepal, where a relatively steady subsidence and sedimentation between 1 and $3 \mathrm{~cm} / \mathrm{k} . \mathrm{y}$ takes place until mid-Cretaceous time (Fig. 12). Decompacted sedimentation rates were estimated to have varied from to $2.5 \mathrm{~cm} / \mathrm{k}$.y. Taking into account the paucity of geological age dates for Thakkhola, in all but the Nupra Formation, subsidence appears to have been relatively steady since the Triassic and into mid-Cretaceous time.

The significance of the 9 m.y. hiatus in the Callovian-Oxfordian was discussed previously; in Nepal this does not constitute an unconformity, and nondeposition (stratigraphic condensation) at the onset of a major (global) transgression may be the cause, rather than tectonic uplift, tilting, and erosion. No evidence has been found from the Thakkhola burial rates for changing, intermittent tectonic subsidence as the cause for changes in sedimentary facies through time. A general increase in sedimentation rate in Late Jurassic time may relate to Gondwana margin rifting described earlier, and the higher rate around $120 \mathrm{~m}$.y. ago may be a reflection of the post-rift volcanic episode (Fig. 12).

The central Exmouth Plateau subsided extensively at the rifting and onset of seafloor spreading in the Argo Abyssal Plain (Sites 261 and 765), approximately $150 \mathrm{~m} . y$. ago. Relatively high continental margin sedimentation rates occurred at that time at Site 763 , varying from about 5 to $15 \mathrm{~cm} / \mathrm{k} . \mathrm{y}$. for a brief, $10 \mathrm{~m} . \mathrm{y}$. period.

The Wombat Plateau subsided extensively during late Triassic-Early Jurassic time, but experienced major uplift, block tilting, and subaerial erosion during a local Callovian/Oxfordian tectonic event that formed a major unconformity over the plateau. Rapid subsidence as a result of breakup followed during the Tithonian (about 150 m.y. ago), when the adjacent Argo Abyssal Plain was created.

Breakup and oceanic subsidence were initiated in the Gascoyne Abyssal Plain at about $130 \mathrm{Ma}$, when this plain started to subside rapidly (Fig. 13). The Gascoyne breakup event, precisely described by the burial path of Site 766, on the central Exmouth Plateau resulted in nondeposition or erosion followed by Barremian-early Aptian transgression, and on the Argo Abyssal Plain created a sedimentation pulse, a factor two above average. In general, the Argo and Gascoyne abyssal plains are sedimentstarved throughout their late Mesozoic-Cenozoic history; if turbidite and debris-flow deposits are removed from the abyssal sedimentary column, less than $25 \%$ of the column remains to represent true hemipelagic to pelagic sedimentation. At Site 765, the Hauterivian nannofossil chalk of Unit VI (Fig. 4) may reflect a deepening of the $\mathrm{CCD}$, from a shallower position at or above the ridge crest at $2800 \mathrm{~m}$ during Berriasian-Valanginian time. Evidence that Berriasian-Valanginian sediments accumulated at or near the $\mathrm{CCD}$ is provided by strongly etched, pelagic Inoceramus- 


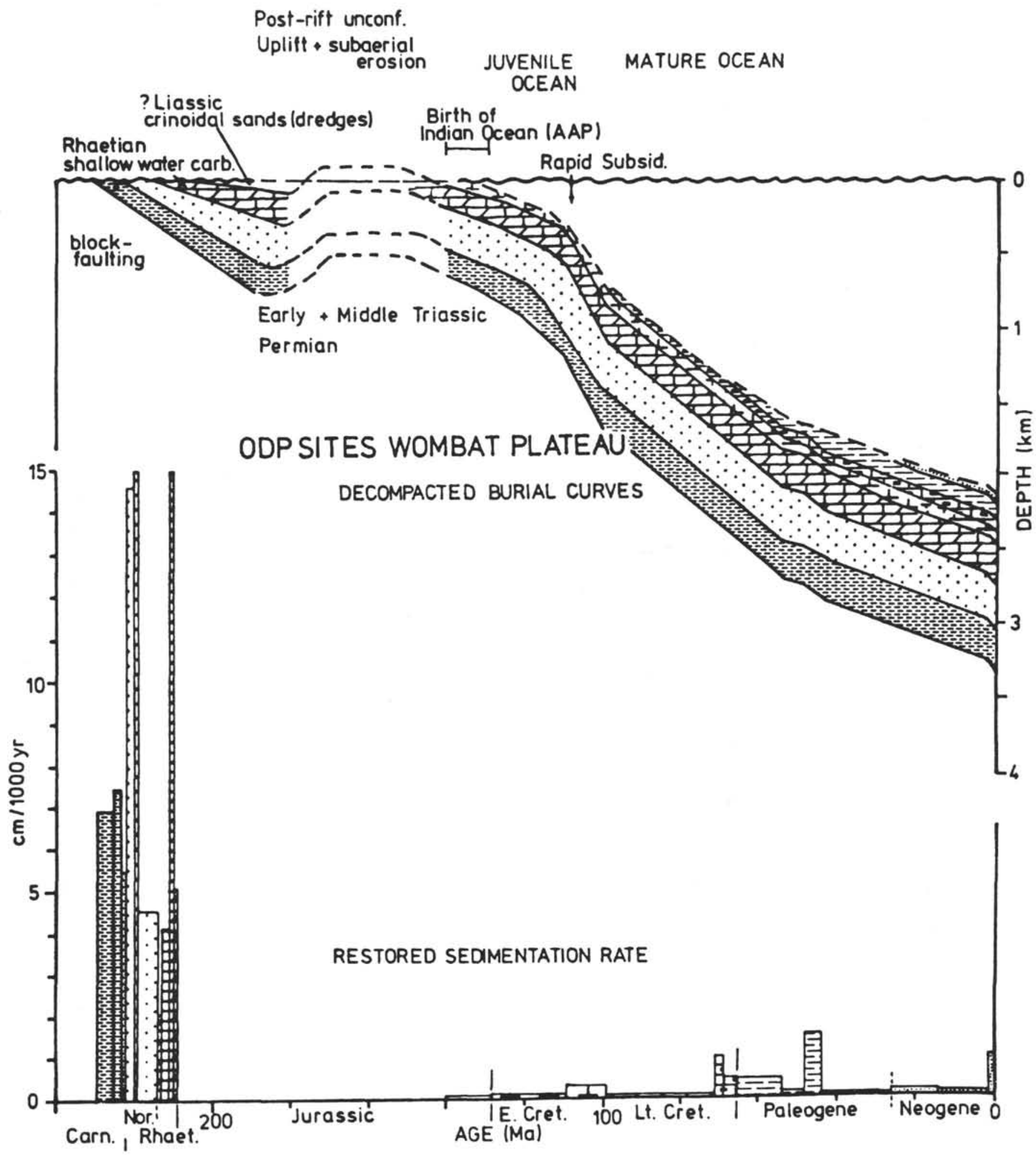

Figure 9. Paleowater depth, burial, and restored sedimentation rates for Wombat Plateau.

type shell fragments and sparse nannofossil assemblages in the basal, red siltstone and claystone of Unit VII. Until today, the $\mathrm{CCD}$ of the Indian Ocean has decreased to below $4 \mathrm{~km}$ since Cretaceous time.

The foregoing demonstrates the first-order effect of rifting, breakup, and ocean spreading tectonics on the regional burial and sedimentation history of the northwestern Australian continental margin; but curiously, this is not immediately obvious from the Thakkhola burial and sedimentation data. Nevertheless, a general increase in sedimentation rate in the Late Jurassic may relate to the Gondwana margin breakup described earlier. More detailed biostratigraphic analysis for Thakkhola, Nepal, will clarify the 



Figure 10. Paleowater depth, burial, and restored sedimentation rates for Site 765 and restored sedimentation rates for Site 261, Argo Abyssal Plain.

relationship between sedimentation and the principal tectonic events that modified and ultimately destroyed the Mesozoic northern Gondwana continental margin basins.

Our stratigraphic data confirm that the Triassic-Lower Cretaceous sedimentary succession of Thakkhola, Nepal, may be related to that found on the Exmouth and Wombat plateaus, off northwestern Australia, which supports the interpretation that both regions were contiguous as part of the Gondwana continental margin until at least Early Cretaceous time.

\section{ACKNOWLEDGMENTS}

I thank all participants of Legs 122 and 123 for their enthusiastic and excellent cooperation on board the JOIDES Resolution, and for their contribution to the outstanding success of both 
ODP SITE 762:CENTRAL EXMOUTH PLATEAU

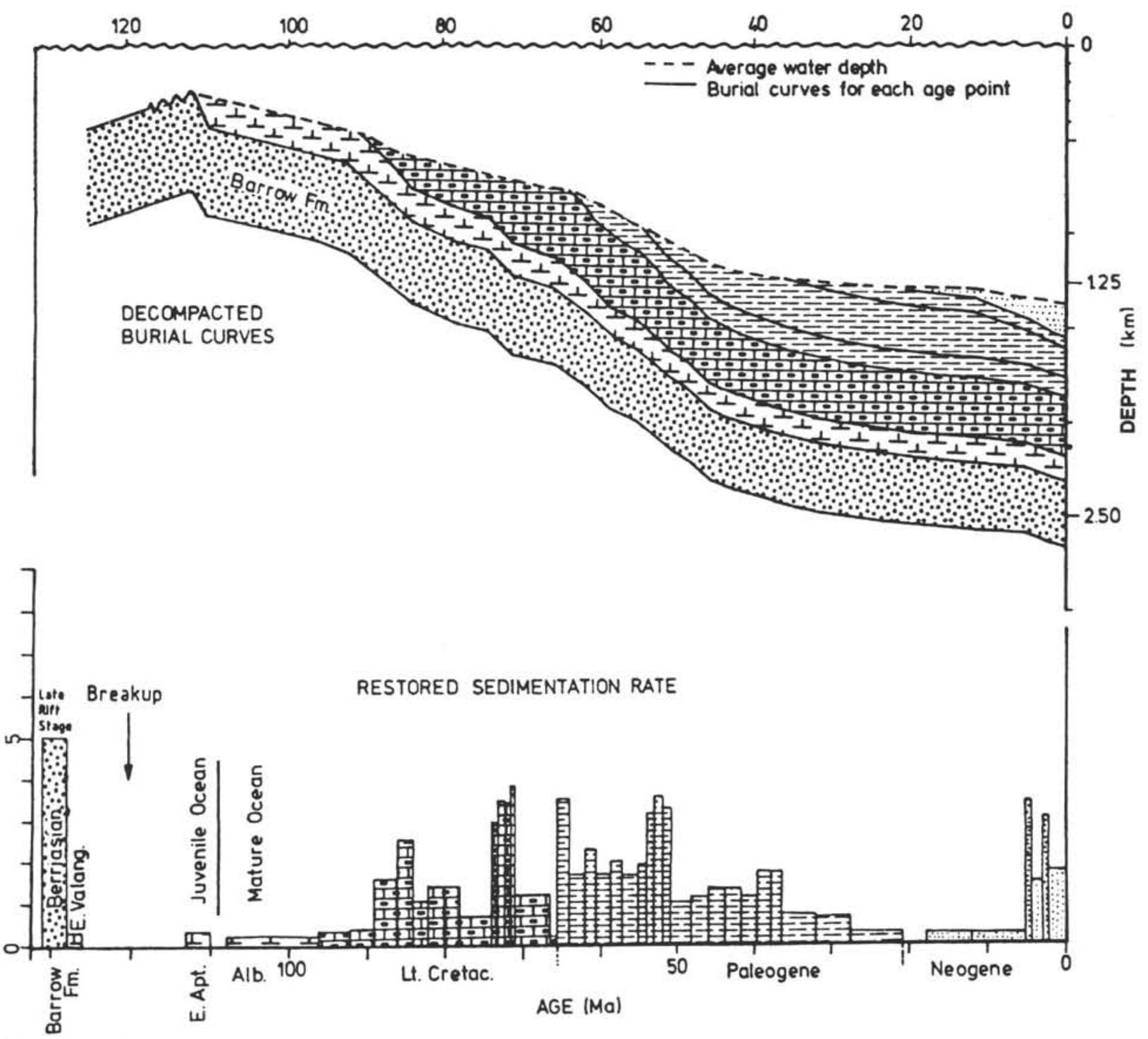

Figure 11. Paleowater depth, burial, and restored sedimentation rates for Site 762, central Exmouth Plateau.

cruises. The Ocean Drilling Program at Texas A\&M University provided the sophisticated logistical and technical support for these technically complex drilling legs. J. Ludden, J. Ogg , U. von Rad, and J. Mutschler-Fontenot critically read the manuscript and suggested valuable improvements.

\section{REFERENCES}

Barber, P. M., 1982. Paleotectonic evolution and hydrocarbon genesis of the central Exmouth Plateau. APEA J., 22:131-144.

Boyd, R., Williamson, P., and Haq, B., in press. Seismic stratigraphy and passive margin evolution of southern Exmouth Plateau. In von Rad, U., Haq, B. U., et al., Proc. ODP, Sci. Results, 122: College Station, TX (Ocean Drilling Program).

Erskine, R. D., and Vail, P. R., 1988. Seismic stratigraphy of the Exmouth Plateau. In Bally, A. W. (Ed.), Atlas of Seismic Stratigraphy. AAPG Stud. Geol., 27:163-173.
Exon, N. F., von Rad, U., and von Stackelberg, U., 1982. The geological development of the passive margins of the Exmouth Plateau off northwest Australia. Mar. Geol., 47:131-152.

Exon, N. F., and Willcox, J. B., 1978. Geology and petroleum potential of the Exmouth Plateau area off Western Australia. AAPG Bull., 62:40-72.

Exon, N. F., Williamson, P. E., von Rad, U., Haq, B. U., and O'Connell, S., 1989. Ocean drilling finds Triassic reef play off NW Australia. Oil \& Gas J., 87:46-52.

Fullerton, L. G., Sager, W. W., and Handschumacher, D. W., 1989. Late Jurassic-Early Cretaceous evolution of the eastern Indian Ocean adjacent to Northwest Australia. J. Geophys. Res., 94:2937-2953.

Gradstein, F. M., Fearon, J. M., and Huang, Z., 1989a. BURSUB and DEPOR version 3.50 - two FORTRAN 77 programs for porosity and subsidence analysis. Open-File Rep.-Geol. Surv. Can., 1283:1-10.

Gradstein, F. M., Gibling, M. R., Jansa, L. F., Kaminski, M. A., Ogg, J. G., Sarti, M., Thurow, J. W., von Rad, U., and Westermann, G.E.G., 
1989b. Mesozoic Stratigraphy of Thakkhola, Central Nepal. Spec. Rep. Cent. Mar. Geol. Dalhousie Univ., 1:1-115.

Gradstein, F. M., Gibling, M. R., Sarti, M., von Rad, U., Thurow, J. W., Ogg, J. G., Jansa, L. F., Kaminski, M. A., and Westermann, G.E.G., in press. Mesozoic Tethyan strata of Thakkhola, Nepal: evidence for the drift and breakup of Gondwana. Palaeogeogr., Palaeoclimatol., Palaeoecol.

Haq, B. U., Hardenbol, J., and Vail, P. R., 1988. Mesozoic and Cenozoic chronostratigraphy and cycles of sea-level change. In Wilgus, C. K., Hastings, B. S., Kendall, C.G.St.C., Posamentier, H. W., Ross, C. A., and Van Wagoner, J. C. (Eds.), Sea-Level Changes-An Integrated Approach. Spec. Publ.-Soc. Econ. Paleontol. Mineral., 42:71-108.

Haq, B. U., von Rad, U., O'Connell, S., et al., 1990. Proc. ODP, Init. Repts., 122: College Station, TX (Ocean Drilling Program).

Heirtzler, J. R., Cameron, P., Cook, P. J., Powell, T., Roeser, H. A., Sukardi, S., and Veevers, J. J., 1978. The Argo Abyssal Plain. Earth Planet. Sci. Lett., 41:21-31.

Kent, D. V., and Gradstein, F. M., 1985. A Cretaceous and Jurassic geochronology. Geol. Soc. Am. Bull., 96:1419-1427.

Larson, R. L., 1975. Late Jurassic seafloor spreading in the eastern Indian Ocean. Geology, 3:69-71.

Le Fort, P., 1989. The Himalayan orogenic segment. In Sengör, A.M.C. (Ed.), Tectonic Evolution of the Tethyan Regions. NATO ASI Ser., Ser. C, 259:289-386.

Ludden, J. N., Gradstein, F. M., et al., 1990. Proc. ODP, Init. Repts., 123: College Station, TX (Ocean Drilling Program).

Mutter, J. C., Larson, R. L., and Northwest Australia Study Group, 1989. Extension of the Exmouth Plateau, offshore northwestern Australia: deep seismic reflection/refraction evidence for simple and pure shear mechanisms. Geology, 17:17-21.

Sarti, M., Russo, A., and Bosellini, F. R., in press. Rhaetian Strata, Wombat Plateau: Analysis of Fossil Communities as a Key to Paleoenvironmental Changes. In von Rad, U., Haq, B. U., et al., Proc. ODP, Sci. Results, 122: College Station, TX (Ocean Drilling Program).

Sclater, J. G., Meinke, L., Bennett, A., and Murphy, C., 1985. The depth of the ocean through the Neogene. In Kennett, J. P. (Ed.), The Miocene Ocean: Paleoceanography and Biogeography. Mem. Geol. Soc. Am., $163: 1-20$.

Sengör, A.M.C., 1985. The story of Tethys-how many wives did Okeanus have? Episodes, 8:1-12.

Stam, B., Gradstein, F. M., Lloyd, P., and Gillis, D., 1987. Algorithms for porosity and subsidence history. Computers and Geosci., 13:317349.
Veevers, J. J., Heirtzler, J. R., et al., 1974. Init. Repts. DSDP, 27: Washington (U.S. Govt. Printing Office).

Veevers, J. J., Tayton, J. W., and Johnson, B. D., 1985. Prominent magnetic anomaly along the continent-ocean boundary between the northwestern margin of Australia (Exmouth and Scott Plateaus) and the Argo Abyssal Plain. Earth Planet. Sci. Lett., 72:415-426.

von Rad, U., and Exon, N. F., 1983. Mesozoic-Cenozoic sedimentary and volcanic evolution of the starved passive continental margin off northwest Australia. In Watkins, J. S., Drake, C. L., and Sheridan, R. E. (Eds.), Studies in Continental Margin Geology: AAPG Mem., 34:253-281.

von Rad, U., Haq, B. U., and Exon, N. F., in press. Early rift to drift evolution of the Wombat Plateau (NW Australia): a synthesis of ODP Sites 759-761 and 764. In von Rad, U., Haq, B. U. et al., Proc. ODP, Sci. Results, 122: College Station, TX (Ocean Drilling Program).

von Rad, U., and Thurow, J., in press. Bentonitic clays as indicators of early Neocomian post-breakup volcanism off NW Australia (ODP Leg 122). In von Rad, U., Haq, B. U., et al., Proc. ODP, Sci. Results, 122: College Station, TX (Ocean Drilling Program).

von Rad, U., Thurow, J., Haq, B. U., Gradstein, F., Ludden, J., and ODP Leg 122/123 Shipboard Scientific Parties, 1989. Triassic to Cenozoic evolution of the NW Australian continental margin and the birth of the Indian Ocean (preliminary results of ODP Legs 122 and 123). Geol. Rundsch., 78:1189-1210.

von Stackelberg, U., Exon, N. F., von Rad, U., Quilty, P., Shafik, S., Beiersdorf, H., Seibertz, E., and Veevers, J. J., 1980. Geology of the Exmouth and Wallaby Plateaus off northwest Australia: sampling of seismic sequences. BMR J. Aust. Geol. Geophys., 5:113-140.

Williamson, P. E., Exon, N. F., Haq, B. U., von Rad, U., and Leg 122 Shipboard Scientific Party, 1989. A Northwest Shelf Triassic reef play: results from ODP Leg 122. APEA J., 29:328-344.

Yeates, A. N., Bradshaw, M. T., Dickens, J. M., Brakel, A. T., Exon, N. F., Langford, R. P., Mullholland, S. M., Totterdell, J. M., and Yeung, M., 1986. The Westralian superbasin: an Australian link with Tethys. In McKenzie, K. G. (Ed.), Shallow Tethys 2: Rotterdam (A. A. Balkema), 199-213.

Date of initial receipt: 14 February 1991

Date of acceptance: 28 June 1991

Ms 123B-110 


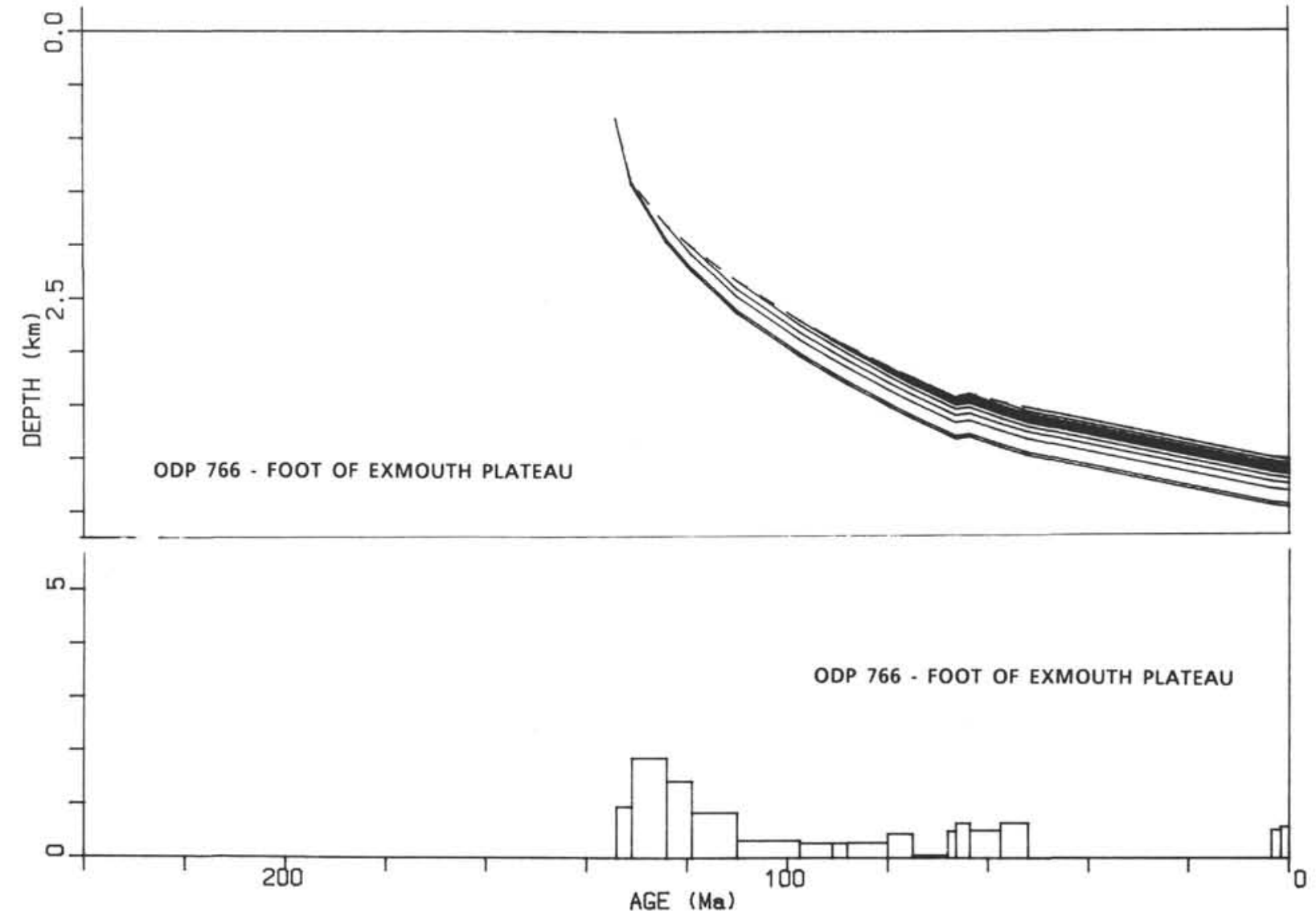

Figure 12. Paleowater depth, burial, and restored sedimentation rates for Site 766, foot of Exmouth Plateau leading onto the Gascoyne Abyssal Plain. 


\section{F. M. GRADSTEIN}

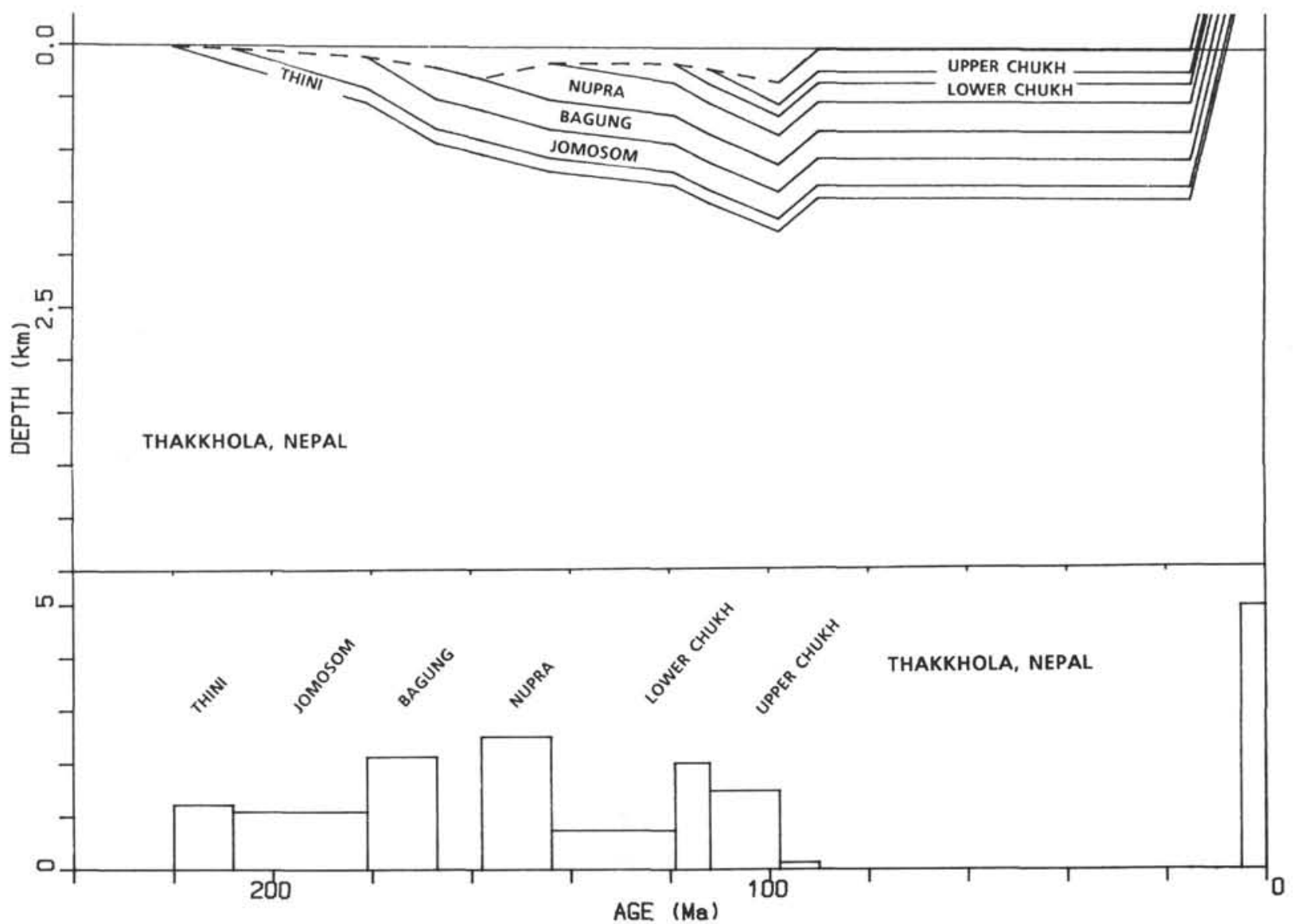

Figure 13. Paleowater depth, burial, and restored sedimentation rates for Mesozoic formations in Thakkhola, Nepal. A detailed discussion of the regional stratigraphy is found in Gradstein et al. (1989b; in press). 